\title{
Lexis
}

Journal in English Lexicology

Book reviews | 2013

\section{Kristel PRoost, Conceptual Structure in Lexical Items}

John Benjamins Publishing Company, 2007, 304 pages

\section{Antoine Consigny}

\section{Q OpenEdition}

Journals

Electronic version

URL: http://journals.openedition.org/lexis/1873

DOI: $10.4000 /$ lexis. 1873

ISSN: 1951-6215

\section{Publisher}

Université Jean Moulin - Lyon 3

Electronic reference

Antoine Consigny, "Kristel proost, Conceptual Structure in Lexical Items», Lexis [Online], Book reviews, Online since 17 October 2013, connection on 24 September 2020. URL : http:// journals.openedition.org/lexis/1873; DOI : https://doi.org/10.4000/lexis.1873

This text was automatically generated on 24 September 2020

\section{(c) (i) (9)}

Lexis is licensed under a Creative Commons Attribution-NonCommercial-NoDerivatives 4.0 International License. 


\title{
Kristel PROOST, Conceptual Structure in Lexical Items
}

John Benjamins Publishing Company, 2007, 304 pages

\author{
Antoine Consigny
}

\section{REFERENCES}

Kristel Proost

Conceptual Structure in Lexical Items. John Benjamins Publishing Company, Pragmatics \&Beyond New Series, ed. Andreas H. Jucker. Amsterdam and Philadelphia, 2007. ISBN: 9789027254122, Prix : $110 €, 304$ pages

1 The book is 304 pages long, including appendices (76 pages), a 6-page list of references and two indexes (author/subject and verbs/phrasemes discussed), and is the published version of a PhD thesis submitted in 2005 at the University of Mannheim, Germany.

In the Introductory chapter, Proost briefly presents the main research topic and the terminology used. The study is concerned with the lexicalisation - or non-lexicalisation - of concepts of verbal communication. The originality of the approach lies in her studying not only existing lexical items, but also what she refers to as 'lexical gaps', i.e. potential concepts which fail to be lexicalised. Three languages studied - German, English and Dutch, the aim being to provide a cross-linguistic analysis of the phenomenon. French and Turkish are also mentioned, though in less detail. The study looks at the semantics of verbs, described in terms of features. A distinction is made between 'speech act verbs' (which lexicalise the speaker's attitude towards the proposition (P) and/or their intention relative to $\mathrm{P}$ ) and 'verbs of communication' (which lexicalise the act itself, or the way/medium etc. in which the act is performed, the speaker's attitude being optional).

In Chapter 2, the author discusses various organising systems for classifying and describing concepts of communication. She first discards Austin's (1962) classification of speech acts. According to her, it is incomplete because mainly concerned with 
performatives and, as a result, is of little use in looking at lexical gaps since it is based solely on existing lexical items. She continues the discussion of performative verbs with Searle's (1975) account of the problem and concludes that performativity is not a valid category for describing concepts of communication. She then turns to other descriptions such as Baumgärtner's (1977) and Edmondson's (1981). The former describes 'categorial aspects', which Proost sees as 'aspects of the meaning of performative illocutionary verbs determining in what kinds of situations those predicates may be used' (p.35). Examples include 'evaluation of P' (as positive or negative, as in praise and vcriticise) and 'temporal reference of $\mathrm{P}$ ' (past, present or future). It is possible to make sets, thus creating a matrix for the description of concepts (whether lexicalised or not). The model is however incomplete because it covers only two types of verbs - directives and commissives. Edmondson's model adopts a similar method, creating a matrix of features, and covers more types of verbs. It is, however, less precise because it has too few conceptual categories, and is also rejected. Proost finally considers Harras' (1994) ordering system for concepts of communication. From this, and taking into account other models (especially Baumgärtner's), she presents her own categorial aspects, which 'are the results of an analysis of the illocutionary verbs of a particular language' (p. 79), namely German. She considers the propositional content (P), the propositional attitude (S), i.e. the speaker's attitude towards (P), the speaker's intention (I) and the presuppositions, about the interaction and about the situation. Each is given attributes, which are assigned potential values (e.g. temporal reference: 'present/past/future'; evaluation: positive/ negative, etc.). Having adopted Harras' ordering system, she makes a final distinction between lexical gaps and 'matrix products' (p. 83). These are combinations resulting from the matrix but which do not correspond to concepts of communication, i.e. they are combinations of values which 'do not make sense from a communicative point of view' (p. 83). She can then proceed to the next chapter, which is the heart of the study.

Chapter 3 is devoted to examining lexical gaps, i.e. concepts of communication which fail to be lexicalised. Initially, she briefly justifies her topic, for three reasons. First, lexical gaps may be useful in finding (or confirming) patterns in the distribution of existing lexicalisations. Secondly, lexical units and free combinations of words do not have the same status in a speaker's memory, the former being more easily available. Her third reason is that 'language and thought are often claimed to be related' (p. 91). According to her, a lexical gap for a given concept indicates that this concept is not salient for speakers: 'where special verbs for certain utterances are missing, these utterances have not acquired the status of speech acts and hence they have not developed into social institutions' (p. 94-95). The chapter moves on to a presentation of previous studies on lexical gaps, which enables Proost to give her definition and criteria for lexical gaps: 'an empty slot in the structure of a lexical field resulting from the absence of a special lexical item $x$ for a concept $y$ which is part of a conceptual system $\mathrm{z}$ and corresponds to an event, action or state of affairs which is practically conceivable' (p.115). The next - and most important - part of the chapter is a very detailed analysis of the lexical gaps found in speech act verbs and verbs of communication. Each conceptual field is studied in turn, yielding an exhaustive description of what is lexicalised as well as what is not. Looking at the many lexical gaps, Proost finds that most of them fall into 7 patterns. One example is the fact that there are more lexical gaps for future reference than past reference. Explanations are then offered for those patterns. In particular, two pragmatic principles emerge 
(p. 156-157) - the Principle of Markedness (marked patterns of behaviour are more often lexicalised) and the Principle of costs and Benefits ('only speech act concepts involving costs as well as benefits get lexicalised', p. 156).

5 The fourth chapter is concerned with complex lexicalisations, idioms and collocations. The aim is to compare them to simple verbs, looking more specifically at the following two questions:

- Is there more (or less) complexity in the concepts expressed by multi-word expressions?

- Is there more (or less) evaluation?

She considers German expressions taken from the Duden dictionary of idioms (1988), excluding 'expressions which are becoming outdated [...], expressions which are not used primarily to refer to communicative acts [...] and idioms and collocations expressing a disposition' (p. 166). The various units are divided into fully idiomatic expressions, semi-idioms and collocations. This gives a total of 676 expressions, with 402 idioms, 72 semi-idioms and 202 collocations. She then compares them with lexical fields of speech act verbs and verbs of communication. She first looks at the 441 complex lexicalisations (65.2\% of the total) that have a one-word synonym, and concludes that evaluation is not done only by idioms but by single verbs as well. She then turns to those which do not have a one-word equivalent. They are of three types. First, 189 of them (80.4\% of the remaining 235 complex lexicalisations) expand the meanings of existing speech act verbs or verbs of communication. Another $20(8.5 \%)$ belong to existing fields, but either they add some elements which do not belong to an existing field, or they belong to several fields at a time. As a result, they can be seen as forming 'hybrid' classes of communicative expressions. The remaining 26 complex lexicalisations do not belong to any existing fields of communicative expressions and therefore constitute separate classes. She concludes with a number of general principles describing lexicalisation patterns.

6 In the concluding chapter, Proost sums up the findings of the study. She takes up the two principles for lexicalisation of communication concepts: the principle of costs and benefits (for commissives and directives) and the principle of markedness (for evaluations and emotions). The two are mutually exclusive, but they work better as two separate principles than as a general one that would aim to cover all cases. On complex lexicalisations, she concludes that they do not really fill lexical gaps, but are used more frequently to expand the meanings of existing lexicalisations.

7 The study presented in the book is a very thorough and detailed analysis of the semantics of a specific aspect of verbs - speech act verbs and verbs of communication. Using a model developed mainly from Harras, but drawing from others as well (notably Baumgärtner and Edmondson), Proost shows that a feature analysis can reveal and describe concepts quite efficiently. The number of verbs and expressions studied enables her to draw conclusions that hold for the German language in a justifiable way. However, the book lacks examples, notably attested ones. The BNC is used in a few cases but only sporadically, and hardly any real examples come to support the analyses presented. This is all the more surprising as she claims to be looking at pragmatic meaning as well as lexical semantic meaning.

First, she describes the meaning of boast as 'Sa evaluates one of his own past actions positively, while Sd believes Sa's act of self-praise to be exaggerated' (p. 28). Yet, 
evidence from the BNC shows that the verb, though it does include a positive evaluation, does not always include a negative one, as in the example below:

CHOICE Hotels International has opened its first hotel in Thailand, the Quality Hotel Pinnacle in Bangkok. The newly constructed 166-bedroom hotel is situated in the business district and boasts a business centre, restaurant, poolside gardens and 24hour limousine service. Choice Hotels is looking to expand in Thailand with a target of 30 hotels in the country within 10 years.

9 This kind of example is not at all uncommon and shows that the utterer does report a positive evaluation, but that this positive evaluation is not necessarily considered exaggerated.

Secondly, her claims would become more convincing with reference to attested examples as well as usage-based statistics. For instance, she compares warn and threaten and writes that warn is typically used by a [resource situation, i.e. the one referred to] speaker addressing a future event/state in which the hearer rather than the speaker himself is involved' (p. 49). Such a claim definitely needs support from corpus data, especially as these are now readily available.

In a word, this convincing and well-argued study already worthy piece of work could be expanded and made even better by incorporating lists of examples and some statistics to complement the (exhaustive) list of lexical units analysed.

\section{AUTHORS}

\section{ANTOINE CONSIGNY}

Antoine Consigny, département d'Études Anglaises et Nord-Américaines de l'Université de Strasbourg, France.

Antoine Consigny est maître de conférences au département d'Études Anglaises et NordAméricaines de l'Université de Strasbourg, où il enseigne la linguistique anglaise de la 1 ère année à l'agrégation. Il a soutenu à Liverpool en 2002 une thèse sur la sémantique des verbes à particules, et a poursuivi ses recherches en sémantique, en particulier en sémantique verbale, et en grammaire. 